\title{
Critical Education beyond Capital: Challenges on Overcoming Social and Scholar Inequalities over the Stage of Contemporary Education Policies
}

\author{
Maurício Roberto da Silva*, Miguel Ângelo Silva da Costa, Luci dos Santos Bernardi \\ Department of Education, Universidade Comunitária da Região de Chapecó, UNOCHAPECO, Chapecó, Brazil \\ Email: ${ }^{*}$ mauransilva@gmail.com
}

Received 14 January 2015; accepted 24 March 2015; published 25 March 2015

Copyright @ 2015 by authors and Scientific Research Publishing Inc.

This work is licensed under the Creative Commons Attribution International License (CC BY).

http://creativecommons.org/licenses/by/4.0/

\section{(c) (i) Open Access}

\section{Abstract}

The essay aims to bring the discussion concerning the "Rule of Critical Education" and its confluence together with "Education beyond Capital". Thus, it is an approach dedicated to reflecting the challenges and possibilities to overcome social and scholar inequalities on the stage of contemporary education policies.

\section{Keywords}

Critical Education, Education beyond Capital, Education Policies, Social and Scholar Inequalities

\section{Introduction: Critical Education and Its Main Task}

On critical attitude

The critical attitude

Strikes many people as unfruitful

That is because they find the state

Impervious to their criticism

But what in this case is an unfruitful attitude

Is merely a feeble attitude. Give criticism arms

And states can be demolished by it.

${ }^{*}$ Corresponding author.

How to cite this paper: da Silva, M. R., da Costa, M. Â. S., \& dos Santos Bernardi, L. (2015). Critical Education beyond Capital: Challenges on Overcoming Social and Scholar Inequalities over the Stage of Contemporary Education Policies. Creative Education, 6, 481-488. http://dx.doi.org/10.4236/ce.2015.64048 


\author{
Canalizing a river \\ Grafting a fruit tree \\ Educating a person \\ Transforming a state \\ These are instances of fruitful criticism \\ And at the same time instances of art. \\ (Bertolt Brecht)
}

The paper intends to discuss "The Task of Critical Education" and its confluence with the "Education beyond Capital", under a perspective that goes beyond the logic of neoliberal capitalism. It is, therefore, an approach dedicated to reflecting the challenges and possibilities of overcoming the social and scholar inequalities, over the stage of contemporary education policies.

Thereby, as a start, we must consider that critical education has been a target for studies from theoretical discussions and concrete motions for intervention and changes in several countries, mainly where education policies are conceived and put in practice based on social and scholar inequalities. Thus, there is a pleiad of critical education studies, which indicate reflections, possibilities of interventions and propositions of change within the emancipatory role and value of education. Indeed, we have been living times of commodification of education and "inclusive exclusion" in the perspective of social apartheid, as well as of neoliberal education policies (Gentili \& Alencar, 2012: p. 33).

It is worth mentioning the relevance of the theoretical-methodological presuppositions of critical education. Particularly, for the perception of power relations and inequalities (social, cultural and economic) present at everyday teaching practices, school and non-school (Apple, Au, \& Gandin, 2011: p. 14). Accordingly, it is important to discuss about a "critical pedagogy", whose conception involves, in a wide dialectic inter-related way, the determinations of class, gender, race/ethnicity, generation and culture.

Thus, what it is highlighted as a permanent challenge is the wider comprehension of critical pedagogy and critical education, whose theory and practice are more and more based on the perception of the importance of multiple dynamics that support the relation between exploration and domination in contemporary society. This means to consider the relevant themes that must be taken as a set, which are related to the redistributive policies (processes, and economic and exploration dynamics), as well as the policies of recognizing (cultural fights against the domination and fights for identity, in terms of gender, race/ethnicity, culture, generation and other sociological categories) (Apple, Au, \& Gandin, 2011: p. 14).

According to Apple, Au, \& Gandin (2011: pp. 14-16), there are eight tasks of critical education. Understood as possibilities of overcoming the issues of education facing neoliberal determinations, these tasks have political and ideological dimensions and can be included in the field of research and action. They are demanding, complex and multidimensional tasks, which intend strict and radical philosophical reflections. Based on the tradition of critical academic thoughts and critical cultural work, through multiple dynamics, it is necessary to "testify the negativity" and recall the collective memory of pedagogic work that is truly counter-hegemonic. It is theoretical and practical political positions, projects and actions, in which the critical analysis, via "critical and transformational intellectuals" of education (Giroux, 1987), must be engaged in the fight for concrete changes in the field of education. Synthetically, we present the eight tasks of Critical Education in Table 1.

\title{
2. Critical Education beyond Capital and Beyond Contemporary Neoliberal Policies
}

Reasoning a critical education beyond capital represents thinking the education as a good of use, not as a good of trade. Education beyond capital, following the perspective of Mészáros quoted by Sader (2005: p. 13), must be debated from the idea that civilizing is not mere transference of knowledge, but also, to make one conscious and witness of life. Educating is humanizing, building up. Likewise, it is to set free the human being from neoliberal deterministic cages, accepting that History is an open field full of possibilities. Educating, thus, is to reiterate by the power of critical knowledge, that the rights we do not exercise are the right we lose. The meaning of discussing education beyond capital relies on educating beyond capital, but also to reason a society beyond capital (Meszárosapud Sader, 2005: p. 13; Gentili \& Alencar, 2012: p. 114). 
Table 1. Tasks of critical education.

Task of Critical Education
$01-$ Critical analysis of policies and
education practices.

education practices.

02-Analysis of contradictions and spaces for possible actions.

03-Redefinition of the object for analysis.

4-Reinterpretation of knowledge

5-Sustenance of the traditions of radical work and critical theories.

6-Critical articulation of new competences.

7-Articulations between critical educators and social movements.

8-Practice instrumentalization of critical knowledge.

\section{Notes and Issues}

The critical analysis must be "testify of negativity", that is, one of its main functions is to shed light on the ways by which the policy and the education practices are connected to relations of exploration and domination - and the fights against those relations - in the society as a whole.

While engaging in such critical analysis, the critical analysis itself must point at the contradictions and possible spaces for actions. Thus, its goal is to look critically over the current realities as a conceptual/political model that emphasizes the spaces where counter-hegemonic actions may be possible to perform or performed indeed.

At this point we refer to actions that challenge the existing relations of unequal power and the so-called "non-reformist reform". This is precisely the task that was admitted in the thick descriptions of scholar practices critically democratic done in "Democratic schools" (Apple \& Beane, 2007).

When Gramsci (1971) urged that one of the tasks of a truly counter-hegemonic education was not to waste the "elite knowledge", but to rebuild its form and content, in a sense that it serves the genuinely progressive and social needs, it has presented a key to another role that the "organic intellectuals" could perform: to develop practice and intellectual/political competences capable of supporting the communities to get involved in the mutually pedagogic debate, which allows that decisions are made according to the middle-term and long-term interests of the oppressed.

In the view of organized attacks to "collective memories" of the differences and social fights, it is absolutely crucial that the traditions are kept alive, renewed, and criticized, when it is necessary, for their conceptual, empirical, historical and political limitations. This also means to keep the dreams, utopic visions and "non-reformist reforms".

The relearning or the development and critical use of new "competences" is crucial in the contemporary setting. One alternative in this case apparently is the necessary critical articulation among journalistic and media, academic and popular competences.

Critical educators must also act together with social movements, or together with the movements against conservative approaches and policies. The academic formation from Critical Education or Critical Pedagogy implies becoming an "organic intellectual" in Gramiscian terms.

This means to support the movements and fights for policies of resource distribution and for social recognition, with specialized knowledge. It also means to use the privilege that we have as academic/activists, in order to make way at universities and some other fields, for the ones who are not there yet, for those who have no voice in such places and at professional area, to which, for the means of the privilege, we have access.

These thoughts about the role of critical education result in the continuous fights for public, free and qualified education. Fights for the existence of "exclusive inclusion" processes; against the historical structure of educational discrimination which has been overlapped to a form of unfair and antidemocratic in the scholar systems. Despite of the possibility of decreasing illiteracy indexes, this does not necessarily mean the end of scholar inequalities, not even the end of segregation policies. It means reinforcing the differentiator dynamics that intensify processes of "exclusive inclusion". Thus, it is necessary to "break with the logic of capital and if we wish to face the creation of an educational alternative meaningfully different, referred by Mészáros (2005: p. 27).

Accordingly, this means that "poor people can access the scholar system, since the existence of educational settings structurally different and segmented is not questioned, those where the quality of education rights is not determined by the quality of resources one owns in order to pay for it" (Gentili \& Alencar, 2012: p. 37). The fact that everyone has access to school does not mean that everyone has access to the same type of schooling. It is possible to affirm that, within twenty years of neoliberal adjustment, the fading of obstacles that prevent the access to schooling must not be understood as the end of discriminatory barriers, but fundamentally its transport to the inside of scholar institution. Therefore, there are different facets of the exclusion processes, and consecutively new scenes of segregation and resistance. According to Gentili \& Alencar (2012: p. 37), "educational exclusion has not stopped, it simply changed its place".

Education beyond capital, further on neoliberal determinisms, cannot defend the rights of private property, the commoditization of education, of free trade. The ideals have subordinated education to market interests, the same way that this ideology has marked out the education principles and values, in all levels and categories. Critical formation, thus, is progressively replaced by a technical formation, with trends to expertise and curricu- 
lar narrowing (Comblin, 1999: pp. 15-24). As defended by neoliberalism, Estate does not participate in Economy, so Education starts to enter capitalist market, taking no more part of the social and political field. Thus, there is a competition for a better educational offer among schools, and parents become simple consumers.

Education, in this sense, starts to reproduce workforce for the capital, assuming the role or enterprise, turning education institutions into knowledge shopping malls" and, this way, educational issues turn into marketing issues. Besides, Education means the process of "internalization" of legitimacy conditions of the system that goes beyond work as merchandise and workers as merchants or merchandise for a passive acceptance. In order to take another condition, producing insubordination, defiance and resistance, Education needs to rediscover its relations with work, with the world of work, with which it shares, among many features, alienation (Mészáros, 2005: p. 17).

Countries in Latin America, among which Brazil, that have made only unassertive changes in social and educational policies and, because of that, are labeled "post-neoliberals", they have the challenge of performing a lurch to the left, aiming to overcome capital values and logic. Such challenge includes rethinking the theory and practice of the so-called "post-neoliberal" governments of Latin America, and, particularly of Brazil. That demands the recognition that, in spite of the fact that there are contradictions and limits in the current policies, it is also necessary to agree that a new step has been taken with the fights against neoliberal doctrine, and consequently some effort to put "social matter" in political and economic agenda (Fagnani, 2014: p. 4).

Thus, when the society beyond capital is at stake, and consequently Education beyond capital, it is necessary to think about political alternatives that are capable of breaking with the neoliberal models of government. In this case, it is worth to remember that, despite the criticism accumulated to neoliberalism, in 2002, when the Party of Workers assumed the Presidence of Brazil, it did devoid of a theoretical horizon dedicated to building a "post-neoliberal society". Accordingly, it is necessary to point at improvement perspectives for Estate policies implanted by Luiz Inácio Lula da Silva and maintained by Dilma Rousseff.

Brazilian context requires the maintenance of historical fights for public and qualified education and in social rights defense. However, that is not enough. It also demands the preservation of the workers achievements and organizations, which were attacked by the government policies, current since the 1990s.

In the book "Lula e Dilma: 10 anos de governospós-neoliberais no Brasil", Sader (2013: p. 141) affirms that, despite all the ills, limitations, misconceptions and contradictions, the commands by Lula and Dilma represent a timid attempt, yet relevant, to break with social inequalities that had longed for decades before, for they have promoted "a remarkable inflection in the evolution of Brazilian social formation". Yet the model remains dominant in world scale, and Brazil is under the influence of regressive transformations performed by neoliberal governments, the mandates by Lula and Dilma, in a sense, put the nation against world trends (Sader, 2013: p. 141).

The challenges faced provide a glimpse of the possibility to build a democratic, solidarity and human society, and this way, to build Education beyond the destructive logic of capital. That implies thinking/making a radical transformation of production, consumption model, work, education, and public policies (Sader, 2013: pp. 41-42; Silva \& Pires, 2014).

\section{Critical Education beyond Capital and the Search for Overcoming Social and Scholar Inequalities}

Social inequality and poverty affect most of the countries of capitalistic society in the contemporary times. That means to affirm that social inequality has as its political-pedagogical and ideological axis the class division, whose repercussions enter the social life of the subjects in the fields of work, economy, culture, education other fields of daily life. The concept of social inequality comprises several kinds of inequalities, which may cover from opportunity and results inequality to literacy, income, and gender, etc. Altogether, economic and social class inequality is imprecisely called social inequality, yet it happens for the unequal distribution of income and material and immaterial richness (Gentili, 2013).

It is worth to reinforce that the historical process of social inequalities production happens in the field of the acknowledged "capital crisis" (Mészáros, 2011), whose historical moment shows, contradictorily, its material "success", its destructive action and a threat to the survival of the planet. Indeed, Mészáros, through a proficient investigation, presents radical and devastating criticism to the gears that characterize the social metabolic system of capital, analyzing the entire twentieth century. The author concludes that the capital system has no limits for 
its expansion, turning into an uncontrollable and deeply destructive process. All this happens for what Marx called "second order mediations", that is, when everything is controlled by the logic of capital appreciation, which does not take into account the vital social human imperatives. The superfluous production and consumption happen to generate the damage of work, which has as its consequence the precariousness and structural unemployment, besides giving impulse to nature destruction in planetary scale and the collapse of work, education, health, habitation, transport policies and so on.

The destructive expansion of capital system happens in connection with the increasing and excessive search for more value, based on unlimited superfluity and disposability. All this process, based on a long period of time, dominated by cycles, makes the system take, according to the formulation by Mészáros, the form of an endemic, chronic, cumulative and permanent crisis. Capital crisis is, therefore, engendered within the society and it is expressed in the dialectic dimension in the world of work and education. Thus, there is no crisis of work and education itself, but social metabolic crisis of capital itself (Antunes, 2011).

Around social and scholar inequalities, the reflection becomes more imminent. Mainly when it is found that, in some departments of academy, there is still a point of view of conservative academic common sense, in which discourse and practices, social inequality is conceived by many as natural and inevitable, since social class inequality or "difference" has always existed and it always will. Thus, for conservative and adapted intellectuals, there is no rupture and possibility of overcoming capital logic. That social representation is still rooted, in heated debate of academic common sense, as well as in informal groups common sense beyond corridors and classrooms at universities, or best, in spontaneous conversation of social daily life (Saviani, 2004).

Everything leads to the perception that the society of goods has not benefited the world population equally. Amid all those processes engendered by capitalistic political economy, huge imbalance occurs among nations, regions and individuals, and they turn into excessive richness and extreme poverty living together in the countryside and urban centers. Social reality in Brazil and Latin America, as well as most regions in the world, has tolerated the existence of hundreds of billionaires that control substantial amount of resources. The production of more richness by capitalists is superior to the one owned by hundreds of millions of individuals. In addition, this reveals that in some countries it is common to face profound contrasts between sumptuous life standards for a few people, and scarcity of elementary goods for the great part of the population in terms of work, education, habitation, leisure and other elements of social and public policies agenda (Cattani, 2010).

Despite the cyclical context described, currently, there is widespread propaganda by the government about the assumed end of extreme poverty. Even so, not even official statistic data and propaganda are enough to end working class misery. One finding is presented: social economic inequalities still have not been reduced and scholar inequalities are still keeping their course. This phenomenon repeats in economically advanced countries, and, fundamentally, in the countries called underdeveloped, or best, peripheral. Thus, we are supposed to question: is it possible to end social inequalities without destroying capitalism and, consequently, to overcome scholar inequalities?

In the wake of debates on social and scholar inequalities, are the reflections and criticism about social and public policies, especially on education policies. It seems to be really topical the critical debate over social inclusion. Furthermore, it is crucial that researchers think critically about the impacts of several government programs for impoverished working classes, among which the controversial "program of income generation" Bolsa Família - a program implanted by the mandate by Lula and kept by Dilma Rousseff.

All these matters raise the need for, while thinking about social and scholar inequalities, doing the critical reflection about the "limits" and the "possibilities" (concrete social impacts or advances caused by social policies, such as Bolsa Família) which are challenges for overcoming social inequalities, and consequently, scholar inequalities.

At this juncture, social inequalities articulate with scholar inequalities, bringing up the so-called "precarious inclusion". This kind of unequal inclusion provides scholar precariousness, with respect to the matters related to teachers work reality (really low wages, too many hours of work, unhealthy working conditions, health, continuing though insufficient education, among other difficulties), as well as related to structure reality of schools, for instance: insufficient equipment and precarious facilities. These issues reach wage earner workers in general, and fundamentally education workers, whose fights show the imminent necessity of claims for better salaries, beyond education policies that promote precarious inclusion and underemployment, that is, the "flexible precariousness", exploitation and impoverishment of the human workforce in public education.

This situation, originated from capital crisis, which engenders the crisis in education, happens to promote, on 
one side, waiver of education, and on the other side, it intensifies political and class fight, nationally and internationally. This fact is illustrated by the several strikes organized by teachers lately these years. The main claim of the current movements of public teachers is related to the abide by the federal law, which implanted, more than two years ago, the "National Salary for Elementary Education Teachers" and, consequently, the claim for public, qualified and society-oriented education. Thus, there is a significant number of protests against spending cuts in Education in several levels of government, and added to that, it is the goal of the government to pay public debt, then finally invest $10 \%$ of GDP in Education.

Even taking all those actions into account, and everything already developed, Brazilian government must implement, urgently, simultaneous policies for appreciation of education professionals. It is necessary to ensure teaching professionalization through initial and continuing education, full application of the law that ensures national professional wages, according to the Article 206 of Federal Constitution, approving and applying the Law of Carrier Guidelines for the category setting. Besides, Brazilian Government also needs to "invest in building new schools and improvement of the existing infrastructure in order to ensure adequate conditions for the teaching-learning process". In addition, it is important to implement and develop democratic scholar management, with a deliberative council composed by representatives from all sectors within local and scholar community, chosen by representative entities. Likewise, preventive and healing measures are necessary for the health of education professionals. These measures will ensure the permanence of the enrolled students, motivating people aged by four to seventeen who are currently away from elementary education in the country (Revista Retratos da Escola da CNTE, 2013).

Despite the obstacles mentioned, teachers' speech evokes and reveals, concomitantly, that it is through hope and utopia of the fight for public and qualified basic education that it will be possible to rescue education from precariousness in the country. Thus, teachers must keep on teaching their students and workmates to be "guardians of doubt and utopia militants" (Gentili \& Alencar, 2012: p. 23), once

There cannot be scholar space disconnected from this conflict, of such booming, these highly original crossroads of humanity. Freedom, coming from the streets, schools, workshops, stages and offices, are also part of the net. In a kaleidoscope of fights, which by its poetry feeds our hope for a world where human beings are not degraded to mere merchandise. We believe in freedom that communicates, that recognizes the structure where it is inserted in order to overcome them, which pervades the transformational mystique of a militant and loving project of creative resistance, in all spaces and through diversified possible ways, including scholar environments (Gentili \& Alencar, 2012: p. 21).

On those evidences emerged in the streets, the theme education policies shall constitute a permanent matter point in debate agenda, especially, in times of cyclic capital crisis, and consequently, education crisis. Thus, it is indispensable to continue, in academic and union terms, the debate and fight for pre-salt royalties destined to education, for "Public, free and qualified education, in all levels" and " $10 \%$ of GDP for public education, immediately". This requires the continuous development of critical debate within academic community. Besides, it is necessary to deepen research, having the relation between theory and practice as central, together with national and international juncture and demands and propositions of the movements in terms of public policies in general, and particularly education policies.

Therefore, it is epistemological and political-ideological emergency, considering the deep and radical issues of capital crisis, its harmful and destructive interference in public policies, mostly education policies. The current international crisis of neoliberal capitalism has raised the take back of the Nation role and the questioning about market and its agents supremacy. The capital crisis and its influences on Nation cannot be viewed separated from the disassemble in social and public policies that happened in "peripheral" and "emerging" countries. All this process is directly articulated to adjust policies and plans by World Bank and IMF. It is connected to the "structural adjust plans" of those international institutions, by its scheme and "interventional packs" and economic stabilization" proposed by the United States of America to national State. The plans, according to Chossudovsky (1999), happen to increase subordination by USA over these multilateral agencies, resulting in the abyssal increase of global poverty, working class and public and social policies impoverishment, and, therefore, social and scholar inequalities.

\section{On a Provisional Conclusion}

By finishing this text and having the expectation of giving contributions to the debate proposed, the provisional 
conclusions that are presented show that the implementation of critical education beyond capital, in terms of post-neoliberal policies, is still a challenge for critical and transformational intellectuals. Thus, there are many tasks to be engendered. As it is our goal to illustrate, all of the tasks involve fights, actions, and projects for formal and non-formal education. The challenges are complex and multidimensional, which circumscribe within critical dimension to social inequalities. They translate the permanent challenge of a wider comprehension of critical pedagogy and critical education, based on the perception of multiple dynamics that support the exploitation and domination relation in contemporary society.

That means to consider the relevant themes that must be approached as a set and relate to redistributive policies (processes and economic dynamics and exploitation), as well as recognition policies (cultural fights against domination and for identity, in terms of gender, race/ethnicity, culture, generation and other sociological categories) (Apple, Au, \& Gandin, 2011: p. 14).

As we have mentioned, within the confluence of critical education with education beyond capital, there is an important challenge: reasoning education as use value, not as trade value. In this case, it is important to emphasize that education beyond capital must be thought from the logic of teaching not as mere knowledge transference, but as awareness and life testifying. Civilizing is to humanize and set free the human being from the cages of neoliberal determinism. Objectively, teaching is to reiterate by the power of critical knowledge, and rights we do not exert are the rights we waste.

These reflections on the role of critical education imply the continuous fights for public, free and qualified education. Objectively, fight against the existence of exclusion processes. Also against the historical structure of educational discrimination and unfair social differentiation. According to Mészáros (2005: p. 27), it is, therefore, necessary "to break with the logic of capital if we wish to view the creation of an education alternative significantly different".

The challenges are huge, but hope is renewed, considering the still small, shy and insecure advances in terms of education policies in Brazil. However, criticism and mobilizations dedicated to changes are not low. Thus, following the thoughts by Gentili \& Alencar (2012), we affirm that Utopic challenges are to educate with hope in disenchantment times.

\section{References}

Antunes, R. (2011). Introduction: Substance Crisis. In I. Mészáros (Ed.), The Structural Crisis of Capital (pp. 4-10). São Paulo: Boitempo. [Antunes, R. (2011). Introdução: substância da crise. In I. Mészáros (Ed.), A crise estrutural do capital (pp. 4-10). São Paulo: Boitempo.]

Apple, M., \& Beane, J. A. (2007). Democratic Schools: Lessons in Powerful Education. Portsmouth, NH: Heinemann.

Apple, M., Au, W., \& Gandin, L. (2011). The Mapping of Critical Education. In M. Apple et al. (Eds.), Critical Education: International Analysis (pp. 14-16). Porto Alegre: Artmed. [Apple, M., Au, W., \& Gandin, L. (2011). O mapeamento da educação crítica. In M. Apple et al. (Eds.), Educação crítica: análise internacional (pp. 14-16). Porto Alegre: Artmed.]

Cattani, A. D. (2010). Wealth and Inequality in Latin America. Porto Alegre, RS: Zouk. [Cattani, A. D. (2010). Riqueza e desigualdade na América Latina. Porto Alegre, RS: Zouk.]

Chossudovsky, M. (1999). The Globalization of Poverty: Impacts of IMF and World Bank Reforms. São Paulo: Moderna. [Chossudovsky, M. (1999). A globalização da pobreza: impactos das reformas do FMI e do Banco Mundial. São Paulo: Moderna.]

Comblin, J. (1999). Neoliberalism: Dominant Ideology at the Turn of the Century. Petrópolis: Vozes. [Comblin, J. (1999). O neoliberalismo: ideologia dominante na virada do século. Petrópolis: Vozes.]

Fagnani, E. (2014) Brazil: Two Projects in Dispute. Le Monde Diplomatique Brasil. [Fagnani, E. (2014) Brasil: dois projetos em disputa. Le Monde Diplomatique Brasil.] http://www.diplomatique.org.br/artigo.php?id=1677

Gentili, P. (2013). Exclusion of Pedagogy: Critique of Neoliberalism in Education. Petrópolis: Vozes. [Gentili, P. (2013). Pedagogia da exclusão: crítica ao neoliberalismo em educação. Petrópolis: Vozes.]

Gentili, P., \& Alencar, C. (2012). Educating in the Hope in Times of Disenchantment. Petrópolis: Vozes. [Gentili, P., \& Alencar, C. (2012). Educar na esperança em tempos de desencanto. Petrópolis: Vozes.]

Giroux, H. (1987). Critical School and Cultural Politics. São Paulo: Cortez. [Giroux, H. (1987). Escola crítica e politica cultural. São Paulo: Cortez.]

Gramsci, A. (1971). The Construction of the Partido Comunista. Turim: Einaudi. [Gramsci, A. (1971). La costruzione del Partido Comunista. Turim: Einaudi.] 
Magazine Pictures of School CNTE (2013). Dossier: Assessment of Basic Education. Brasília, Revista Retratos da Escola, 7. [Revista Retratos da Escola da CNTE (2013). Dossiê: Avaliação da educação básica. Brasília, Revista Retratos da Escola, 7.] http://www.esforce.org.br/index.php/semestral/issue/view/17

Mészáros, I. (2005). Education beyond the Capital. São Paulo: Boitempo. [Mészáros, I. (2005). A educação para além do capital. São Paulo: Boitempo.]

Mészáros, I. (2011). The Structural Crisis of Capital. São Paulo: Boitempo. [Mészáros, I. (2011). A crise estrutural do capital. São Paulo: Boitempo.]

Sader, E. (2013). The Construction of the Neo-Liberal Hegemony. In E. Sader et al. (Eds.), Lula and Dilma: 10 Years Gover Us Post-Neoliberal in Brazil (pp. 135-143.). São Paulo: Boitempo. [Sader, E. (2013). A construção da hegemonia neoliberal. In E. Sader et al. (Eds.), Lula e Dilma: 10 anos de governos pós-neoliberais no Brasil (pp. 135-143). São Paulo: Boitempo.]

Saviani, D. (2004). Education: Common Sense to Philosophical Consciousness. São Paulo: Autores Associados. [Saviani, D. (2004). Educação: Do senso comum à consciência filosófica. São Paulo: Autores Associados.]

Silva, M. R., \& Pires, G. (2014). Elections, Curriculum Parameters, Made, Promises: "What Was Done Should" and "Nothing Like-Ha before". Florianópolis, Motrivivência, 26, 7-16. [Silva, M. R., \& Pires, G. (2014). As eleições, os parâmetros curriculares, os feitos, as promessas: "O que foi feito deverá" e "nada será como antes". Florianópolis, Motrivivência, 26, 7-16.] http://dx.doi.org/10.5007/2175-8042.2014v26n43p7 